Prepared in cooperation with the Bureau of Land Management

Prioritizing Habitats based on Abundance and Distribution of Molting Waterfowl in the Teshekpuk Lake Special Area of the National Petroleum Reserve, Alaska

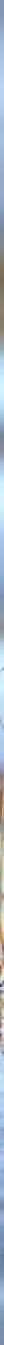

U.S. Department of the Interior U.S. Geological Survey 
Cover: Two Black Brant in a wetland near the Colville River Delta, Alaska. Photograph by Ryan Askren, U.S. Geological Survey, June 6, 2015. 


\title{
Prioritizing Habitats based on Abundance and Distribution of Molting Waterfowl in the Teshekpuk Lake Special Area of the National Petroleum Reserve, Alaska
}

\author{
Paul L. Flint, Vijay Patil, Bradley Shults, and Sarah J. Thompson
}

Prepared in cooperation with the Bureau of Land Management

Open-File Report 2020-1034 


\section{U.S. Department of the Interior DAVID BERNHARDT, Secretary}

\section{U.S. Geological Survey}

James F. Reilly II, Director

U.S. Geological Survey, Reston, Virginia: 2020

For more information on the USGS-the Federal source for science about the Earth, its natural and living resources, natural hazards, and the environment-visit https://www.usgs.gov/ or call 1-888-ASK-USGS (1-888-275-8747).

For an overview of USGS information products, including maps, imagery, and publications, visit https://store.usgs.gov/.

Any use of trade, firm, or product names is for descriptive purposes only and does not imply endorsement by the U.S. Government.

Although this information product, for the most part, is in the public domain, it also may contain copyrighted materials as noted in the text. Permission to reproduce copyrighted items must be secured from the copyright owner.

Suggested citation:

Flint, P.L., Patil, V., Shults, B., and Thompson, S.J., 2020, Prioritizing habitats based on abundance and distribution of molting waterfowl in the Teshekpuk Lake Special Area of the National Petroleum Reserve, Alaska: U.S. Geological Survey Open-File Report 2020-1034, 16 p., https://doi.org/10.3133/ofr20201034.

ISSN 2331-1258 (online) 


\section{Contents}

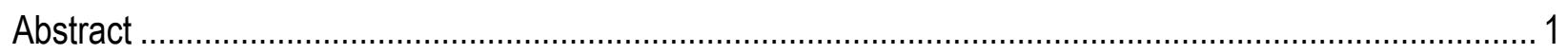

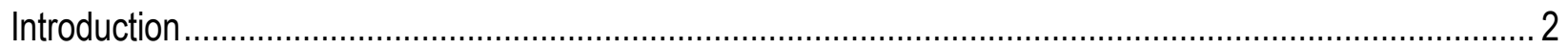

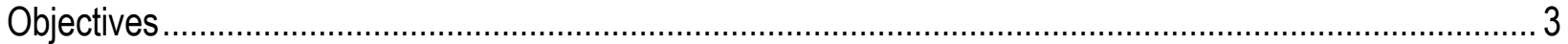

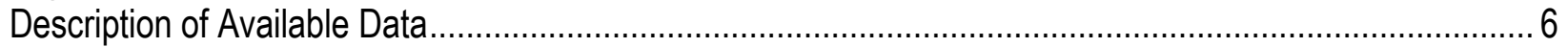

Post-Breeding Molt Survey Data ................................................................................................... 6

Lakeshore-Use Data from Black Brant and Greater White-Fronted Geese ........................................... 6

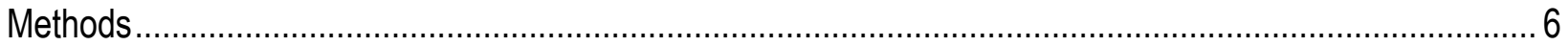

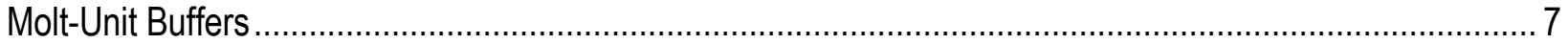

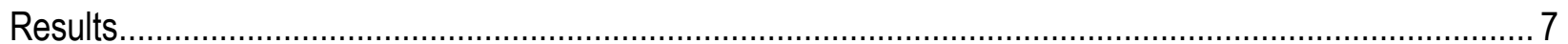

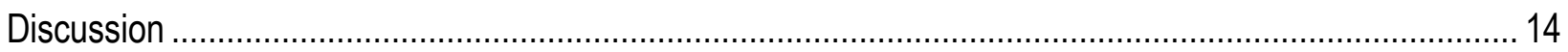

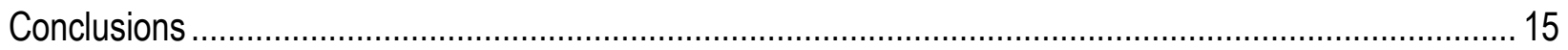

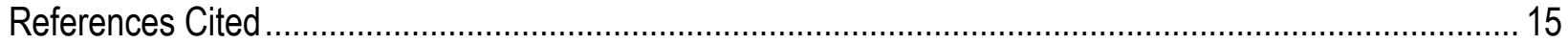

\section{Figures}

Figure 1. Map from the 2008 Record of Decision showing the designated Goose Molting Area within the Teshekpuk Lake Special Area of the National Petroleum Reserve-Alaska...

Figure 2. Map from the 2013 Record of Decision, with the Teshekpuk Lake Special Area shown in the upper right

Figure 3. Cumulative proportion of geese and swans included when molt units in the Goose Molting Area of the Teshekpuk Lake Special Area were selected based on population density of black brant and Canada geese.

Figure 4. Maps showing selected priority habitats for black brant and Canada geese northeastern part of the goose-molting area, Teshekpuk Lake Special Area of the National Petroleum Reserve, Alaska .........11 Figure 5. Comparison of two molt-unit buffer scenarios in the Teshekpuk Lake Special Area of the National Petroleum Reserve, Alaska 13

\section{Tables}

Table 1. Summary statistics for numbers and percentages of goose and swan populations included in fixed buffers along the coastline and the shore of Teshekpuk Lake.

Table 2. Summary statistics for numbers and percentages of goose and swan populations included in selected layers based on thresholds that include $70-90$ percent of the total population. 


\section{Conversion Factors}

U.S. customary units to International System of Units

\begin{tabular}{|c|c|c|}
\hline Multiply & By & To obtain \\
\hline \multicolumn{3}{|c|}{ Length } \\
\hline mile $(\mathrm{mi})$ & 1.609 & ometer $(\mathrm{km})$ \\
\hline \multicolumn{3}{|c|}{ International System of Units to U.S. customary units } \\
\hline Multiply & By & To obtain \\
\hline \multicolumn{3}{|c|}{ Length } \\
\hline centimeter $(\mathrm{cm})$ & 0.3937 & inch (in.) \\
\hline millimeter (mm) & 0.03937 & inch (in.) \\
\hline meter $(\mathrm{m})$ & 3.281 & foot $(\mathrm{ft})$ \\
\hline kilometer $(\mathrm{km})$ & 0.6214 & mile (mi) \\
\hline kilometer (km) & 0.5400 & mile, nautical (nmi) \\
\hline meter $(\mathrm{m})$ & 1.094 & yard (yd) \\
\hline
\end{tabular}

\section{Datum}

Vertical coordinate information is referenced to National Geodetic Vertical Datum of 1929.

Elevation, as used in this report, refers to distance above the vertical datum. 


\title{
Prioritizing Habitats Based on Abundance and Distribution of Molting Waterfowl in the Teshekpuk Lake Special Area of the National Petroleum Reserve, Alaska
}

\author{
Paul L. Flint ${ }^{1}$, Vijay Patil ${ }^{1}$, Bradley Shults ${ }^{2}$, and Sarah J. Thompson ${ }^{1}$
}

\begin{abstract}
The National Petroleum Reserve in Alaska (NPR-A) encompasses more than 9.5 million hectares of federally managed land on the Arctic Coastal Plain of northern Alaska, where it supports a diversity of wildlife, including millions of migratory birds. Within the NPR-A, Teshekpuk Lake and the surrounding area provide important habitat for migratory birds, including large numbers of waterfowl and shorebirds that use the area for breeding and molting. This area has been designated by the Bureau of Land Management as the Teshekpuk Lake Special Area (TLSA) and is estimated to host 22 percent of the entire Pacific black brant (Branta bernicla nigricans) population as it undergoes flightless wing molt. Additionally, numerous other waterfowl species use the area for breeding and molting, including greater white-fronted geese (Anser albifrons), snow geese (Chen caerulescens), Canada geese (Branta hutchinsii), and tundra swans (Cygnus columbianus). A data-derived procedure was developed to define important habitats based on recent distributions of molting birds. That procedure was used to identify areas that could be prioritized for exclusion from oil and gas development within a pre-defined "Goose Molting Area" in the TLSA. This analysis was requested by the Bureau of Land Management to provide information for the development of alternative scenarios for an updated NPR-A, Integrated Activity Plan/Environmental Impact Statement. Habitat selections were based on the population densities of Pacific black brant and Canada geese and pre-defined thresholds for the minimum fraction of the population contained within selected areas. Selections were based on long-term records of population density combined with global-positioning system data to reveal small-scale patterns of habitat use. The highest population density of the Pacific black brant was found along the Beaufort Sea coast on the eastern edge of the study area, whereas Canada geese were somewhat more widely distributed. Depending on the selection criteria and width of protective buffers placed around selected habitat units, 52-85 percent of the Goose Molting Area was identified as high-priority habitat. The effectiveness of this approach to habitat protection assumes that buffers around selected habitat units are wide enough to provide adequate protection from disturbance related to oil and gas development. This assumption remained a key source of uncertainty that could be addressed through additional study of disturbance effects on molting waterfowl.
\end{abstract}

\footnotetext{
${ }^{1}$ Alaska Science Center, 4210 University Drive, Anchorage, Alaska 99508

${ }^{2}$ U.S. Fish and Wildlife Service, Division of Migratory Bird Management, Alaska Region, 1011 East

Tudor Road, Anchorage, Alaska 99503
} 


\section{Introduction}

The National Petroleum Reserve in Alaska (NPR-A) encompasses more than 9.5 million hectares (ha) of federally managed land on the Arctic Coastal Plain (ACP) of northern Alaska, USA, where it supports a diversity of wildlife, including millions of migratory birds. The Bureau of Land Management (BLM) is responsible for regulating the use, occupancy, and development of federal land in the NPR-A to protect wildlife and mitigate the negative effects of oil and gas leasing (Bureau of Land Management, 2015). Within the NPR-A, construction of the first oil-production facility was initiated in 2015, and active leasing and exploratory operations show potential for future oil and gas development (Bureau of Land Management, 2015). The ACP is largely undeveloped and sparsely inhabited, raising concerns about the effects of human activities on the area's abundant wildlife. Potential effects of industrial activity could be indirect (such as destruction of habitat, increased predator abundance through construction of infrastructure) or direct (such as disturbance, displacement of birds caused by human activities), but little is known about the potential magnitude of such effects in undeveloped regions of the Arctic (Hockin and others, 1992; National Research Council, 2003; Liebezeit and others, 2009; Meixell and Flint, 2017). Management agencies are tasked with issuing permits for oil and gas leasing and for infrastructure development such as drill pads, roads, and pipelines, while minimizing disturbance to wildlife. To accomplish this task, managing agencies require a detailed understanding of possible disturbance effects to wildlife but also the abundance, population trends, and spatial distributions of species during key periods in annual cycles, such as the breeding and molting periods for birds.

Within the NPR-A, specific areas are identified for special management considerations based on unique biological or geographic features. Teshekpuk Lake and the surrounding area provide important habitat for migratory birds, including numerous waterfowl and shorebirds that use the area for breeding and molting. The BLM has designated the area of the NPR-A around Teshekpuk Lake as the Teshekpuk Lake Special Area (TLSA), which is estimated to host 22 percent of the entire Pacific black brant population (referred to as black brant in this report; Branta bernicla nigricans) as it undergoes the flightless primary feather molt (Bollinger and Derksen, 1996). Additionally, numerous other waterfowl species use the area for breeding and molting, including greater white-fronted geese (Anser albifrons), snow geese (Chen caerulescens), cackling geese (Branta hutchinsii), and tundra swans (Cygnus columbianus; Flint and others, 2008). Waterfowl undergo a flightless period during their post-breeding molt, and flightless birds are potentially more susceptible to the negative effects of anthropogenic disturbance (Fox and others, 2014). Molting birds have high energy requirements because they need to acquire nutrients necessary for feather production (Fox and others, 2014). If anthropogenic disturbances exclude molting waterfowl from high-quality feeding areas with adequate access to safety, birds may experience decreased survival and increased risk of depredation.

The 2008 BLM Record of Decision (ROD; Bureau of Land Management, 2008) proposed opening the TLSA for petroleum development by leasing large blocks of land and defining parts where no anthropogenic surface occupancy would be allowed in a 0.45-million-acre "Goose Molting Area" within the TLSA (fig. 1). The 2008 decision nominally relied on molting-goose distribution data, but the process by which the data were used to determine the area proposed for "no surface occupancy" was not delineated in the document. This plan was superseded by the 2013 ROD (Bureau of Land Management, 2013), in which the TLSA was expanded from 1.75 million acres to 3.65 million acres (fig. 2). Within this expanded footprint, 3.1 million acres were designated unavailable to leasing and exploratory drilling, and 1.1 million acres were also designated as off limits to new infrastructure, including pipelines (fig. 2). The entire Goose Molting Area was contained within this 1.1-million-acre zone with maximum restrictions on surface development (fig. 2). In 2019, the BLM was tasked with creating alternative scenarios for development within the TLSA, including the Goose Molting Area, as part of a 
revised Integrated Activity Plan/Environmental Impact Statement in which the 2013 ROD represents the "no-action" alternative. This report was produced in response to a request from BLM to evaluate the potential effects of development within the TLSA on wildlife with an emphasis on molting waterfowl.

\section{Objectives}

Our objective was to develop a data-derived procedure to define priority habitats for special management consideration based on recent distributions of molting geese (black brant and Canada geese). Our approach was to reexamine existing datasets to better understand waterfowl use of habitats and regions in the Goose Molting Area of the TLSA during the molting period. The key feature of this approach was to define the criteria for habitat prioritization and then allow the data to determine the minimum area of habitat that meets the criteria. We developed this approach by selecting high-priority habitat for a single species at a time but selecting for multiple species simultaneously could be chosen as a more generalized method. We used a geographic information system (GIS) to quantify the proportions of molting and breeding birds, by species, included in the selected habitats. We focused our analyses on black brant, which is a high-priority species in the TLSA; however, we also explored whether habitat protections based on the distribution of black brant would be an effective strategy for protecting molting areas used by other waterfowl species. 


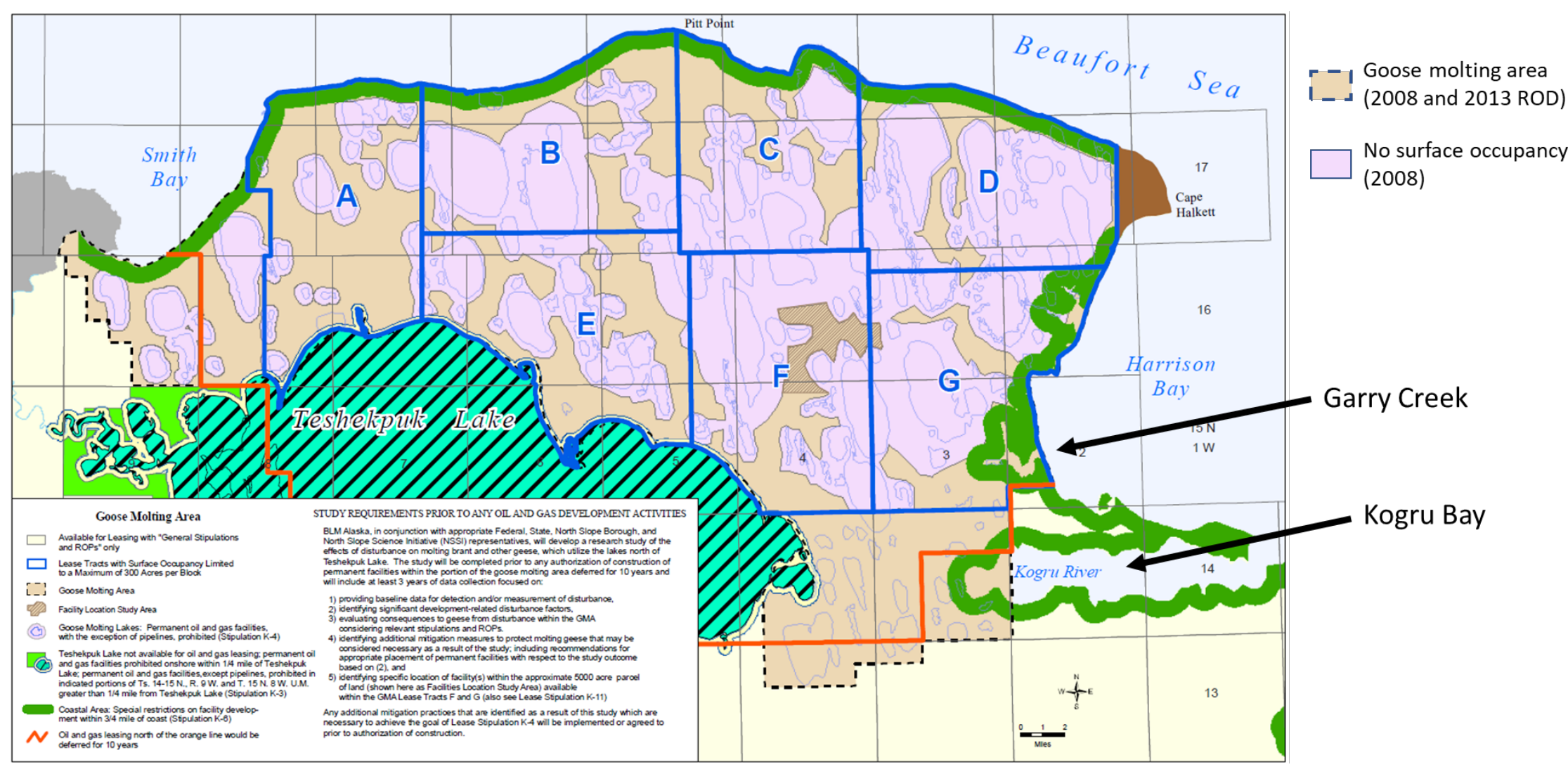

Figure 1. Map from the 2008 Record of Decision (Bureau of Land Management, 2008) showing the designated Goose Molting Area (tan color with dashed line boundary; 0.45 million acres) within the Teshekpuk Lake Special Area of the National Petroleum Reserve, Alaska. Areas in lavender designate "no surface occupancy" in seven proposed lease blocks (labeled A-G and outlined in blue). Black arrows have been added to indicate the locations of Garry Creek and Kogru Bay, two coastal features used as molting habitat by Pacific black brant. 


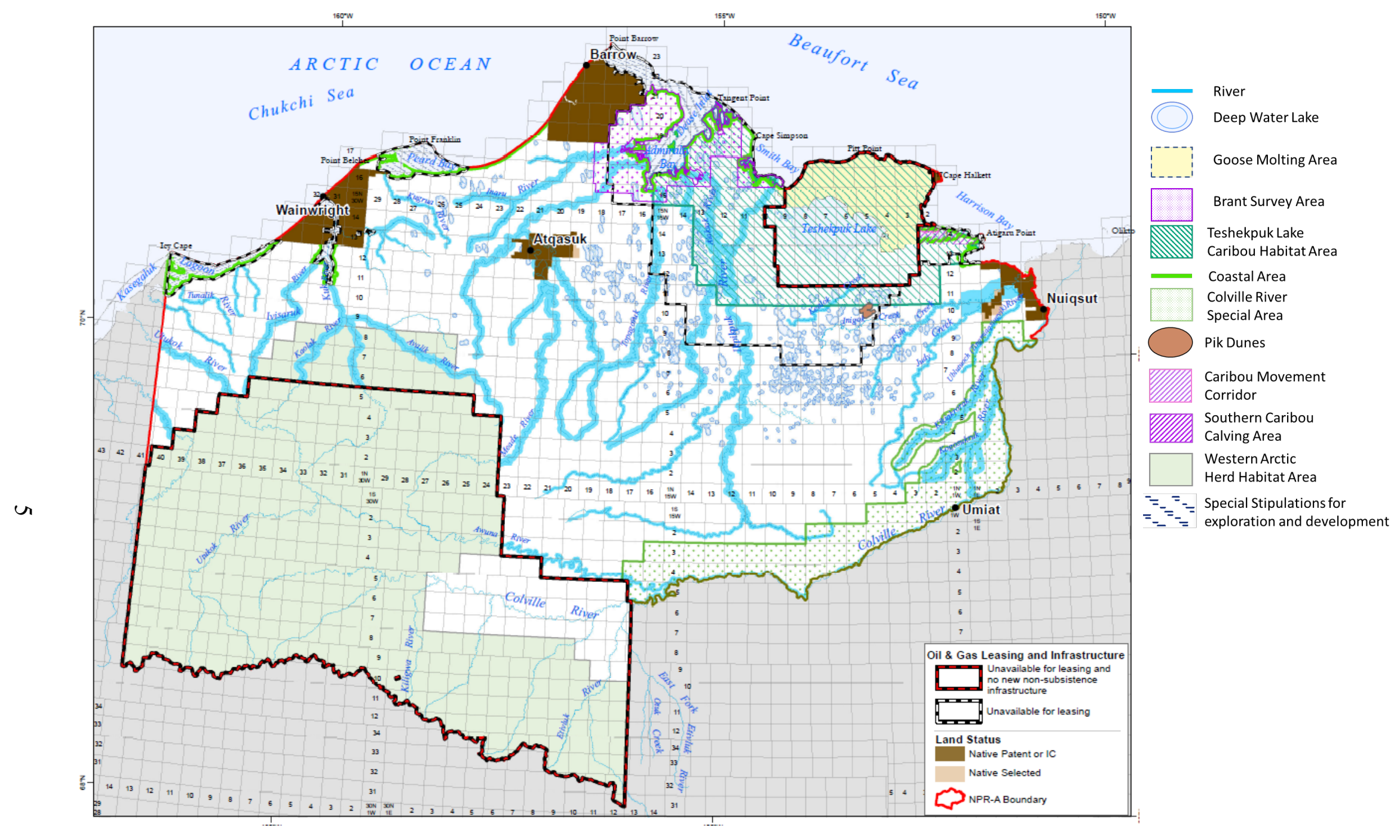

Figure 2. Map from the 2013 Record of Decision, with the Teshekpuk Lake Special Area shown in the upper right (Bureau of Land Management, 2013). The entire Goose Molting Area (yellow area northeast of Teshekpuk Lake) was unavailable for leasing, exploratory drilling, or new infrastructure in the 2013 Record of Decision. 


\section{Description of Available Data}

\section{Post-Breeding Molt Survey Data}

Post-breeding molting-waterfowl survey data consist of more than 30 years of aerial counts done by the U.S. Fish and Wildlife Service, Division of Migratory Bird Management, Alaska Region (Shults and Zeller, 2017). These surveys were done annually in approximately mid-July during the peak of flightless molt for waterfowl in the TLSA. As the pilot and observer fly over the study area, they count waterfowl observed on or near each specific body of water. Thus, flock counts can reveal fine-scale patterns in abundance, both during specified years and as trends through time (for example, different lakes becoming more intensively used in later years of the survey).

\section{Lakeshore-Use Data from Black Brant and Greater White-Fronted Geese}

Molting geese use the surface waters of the lakes in the TLSA as escape and roosting habitat, and they feed along the shorelines of these lakes (Lewis and others, 2011; Flint and Meixell, 2017), so we used Global Positioning System (GPS) location data for flightless black brant (Lewis and others, 2011) and greater white-fronted geese (Flint and Meixell, 2017) to account for fine-scale spatial patterns of terrestrial-habitat use around lakes in our habitat selections. In these datasets, molting black brant were located an average of $31 \mathrm{~m}$ inland from the lakeshore, whereas greater white-fronted geese were located an average of $63 \mathrm{~m}$ inland when flightless. The maximum distance from a lakeshore recorded for undisturbed molting black brant was approximately $800 \mathrm{~m}$ (Lewis and others, 2011), while molting greater white-fronted geese traveled a maximum distance of $1070 \mathrm{~m}$ over land from the nearest lakeshore in the absence of external disturbance (Flint and Meixell, 2017).

\section{Methods}

The molting-goose-survey dataset is based on a long-term study design where individually identified lakes were surveyed and the number of birds counted. Many of these lakes are interconnected and flocks of molting geese can move collectively among lakes from one day to the next. For all spatial analyses, we identified sets of interconnected lakes from satellite imagery and defined them as unique habitat patches that we refer to as molting units (MUs). The survey count for each MU is the sum of the survey counts for each interconnected lake. Using this approach, we identified 139 MUs in the Goose Molting Area delineated by the 2013 ROD.

The landscape of the TLSA is changing rapidly due to coastal thaw and erosion, which has led to increased saltwater incursion into freshwater habitat (Flint and others, 2008; Tape and others, 2013). At the same time, waterfowl species have changed their distribution and abundance (Amundson and others, 2019). Greater white-fronted geese have become seven times more abundant over three decades, whereas the black brant population has remained stable but shifted towards coastal habitat with saltmarsh plant communities (Flint and others, 2008). To account for these recent changes, we restricted our analysis to aerial survey data from 2010 to 2016 to indicate how molting birds are currently distributed in the TLSA. We calculated the average density of each bird species for each MU over these years.

A GIS layer of MUs was derived by merging connected lake polygons from the NHDwaterbody layer produced by the National Hydrography Dataset for Hydrographic Unit (HU) 1906 (U.S. Geological Survey, 2019). At BLM's request, we first created fixed spatial buffer areas that extended $1.6 \mathrm{~km}$ (1 mile) inland from the Beaufort Sea coast, including all major bays and estuaries, and $4.8 \mathrm{~km}$ (3 miles) along the shoreline of Teshekpuk Lake using GIS tools from the rgeos and rgdal packages in R (Bivand and others, 2019; Bivand and Rundel, 2019; R Development Team, 2019). These fixed buffer areas included lands that were considered high priority for reasons other than waterfowl density (for 
example, protection of habitat for caribou). If most of a MU was included in these fixed buffer areas, we considered the entire MU to be covered by the buffer. The coastal buffer included two MUs that were coastal landscape features (Garry Creek estuary and Kogru Bay), both of which consistently supported high densities of molting black brant in the TLSA. We calculated the total areas of these buffers and the proportion of each species within them. We then ranked the remaining MUs in terms of the average densities of black brant and Canada geese (separately) and determined the minimum number of molting units that accounted for 75-90 percent of the total number of birds for each species. This approach provided a series of data layers that represented different levels of population coverage for the priority areas selected in the TLSA .

\section{Molt-Unit Buffers}

Using GIS, we added buffer areas to the perimeter of the lake-defined MUs to include the shoreline habitats that are used by molting birds. For any given selection of MUs, we created $0.8 \mathrm{~km}$ (half-mile) buffers along the shoreline of the water bodies within the MUs, which represented the likely extent of lakeshore habitat used by undisturbed black brant (Lewis and others, 2011). We also created a set of $1.6 \mathrm{~km}$ (one-mile) buffers, which included the region of lakeshore feeding habitat as well as an additional half-mile buffer to account for the potential sensitivity of molting waterfowl to disturbance at a distance. Buffer widths are referred to as half-mile and one-mile hereafter for ease of reference, although all other distance and area measurements are presented in metric units. For each set of buffers, we calculated the total area included within the boundaries of the Goose Molting Area in the TLSA (based on the 2013 ROD), and the proportion of each species (black brant, Canada geese, snow geese, white-fronted geese and tundra swans) that was observed within the selected area. Some molt-unit buffers, including the buffer around Kogru Bay, extended outside of the Goose Molting Area boundaries. The area of buffers included within the Goose Molting Area are reported in the results. However, because MUs represent contiguous habitat patches, surface-occupancy restrictions that cover only a fraction of a MU are unlikely to provide effective protection. Buffers were not truncated in any of the output maps even if a MU extended outside of the original Goose Molting Area boundary.

\section{Results}

The fixed buffer along the coastline included more than 30 percent of the molting black brant (BLBR) population and more than 45 percent of the snow goose (SNGO) population (table 1). Within this buffer, the MU surrounding the inlet of Garry Creek (see fig. 1) accounted for most black brant observations. On average, the Garry Creek MU included 29 percent of the total black brant population that was using the Goose Molting Area in the TLSA. The larger buffer along Teshekpuk Lake included less molting habitat and significant numbers of only greater white-fronted geese (GWFG) and tundra swans (TUSW) (table 1). Because geese are not randomly or uniformly distributed across the landscape, the proportion of the molting population included in any given habitat area was greater than the total proportion of area selected (table 2). Proportional coverages of black brant and Canada geese (CAGO) were similar when molting units were prioritized by Canada goose density (fig. 3). Maps of the coverage selections make it clear that black brant and Canada geese were primarily distributed in the Northeastern part of the goose-molting area (fig. 4); however, selections based on black brant versus Canada geese led to different levels of protection for non-target species (table 2). Specifically, the 85percent CAGO-coverage scenario would have placed surface-occupancy restrictions around MUs containing 81 percent of black brant, 74 percent of snow geese, and 65 percent of greater white-fronted geese, whereas the 85-percent BLBR-coverage scenario would cover only 56 percent of snow geese and 
48 percent of greater white-fronted geese (table 2). Canada geese and black brant were both widely distributed throughout the Goose Molting Area, and a set of buffers covering 90 percent of either black brant or Canada geese would occupy nearly all available surface area (fig. 4).

Table 1. Summary statistics for numbers and percentages of goose and swan populations included in fixed buffers along the coastline (1-mile width) and the shore of Teshekpuk Lake (3-mile width).

[Percentages are shown in parentheses, whereas absolute values (area covered, number of birds) are not. Area and population percentages are in relation to the Goose Molting Area within the Teshekpuk Lake Special Area, as delineated in the 2013 NPR-A Integrated Activity Plan Record of Decision; MU, molt unit. The stated level of protection for each scenario in this report assumes that the buffers around molt units are wide enough to alleviate behavioral and energy-related consequences of disturbance. \%, percent.]

\begin{tabular}{|c|c|c|}
\hline \multirow{2}{*}{ Buffer coverage } & \multicolumn{2}{|c|}{ Fixed Buffer ${ }^{1}$} \\
\hline & Coastal & Teshekpuk Lake \\
\hline Area with half-mile molt-unit buffers ${ }^{2}$ & $344.37(19 \%)$ & $406.13(22 \%)$ \\
\hline Area with one-mile molt-unit buffers ${ }^{2}$ & $358.13(19 \%)$ & $459.68(25 \%)$ \\
\hline Black brant & $5,157(31 \%)$ & $88(1 \%)$ \\
\hline Canada geese & $1,122(8 \%)$ & $446(3 \%)$ \\
\hline Snow geese & $3,572(46 \%)$ & $203(3 \%)$ \\
\hline Greater white-fronted geese & $3,592(9 \%)$ & $3,946(11 \%)$ \\
\hline Tundra swan & $16(6 \%)$ & $75(27 \%)$ \\
\hline
\end{tabular}

${ }^{1}$ Fixed buffers were included in all analyses if a majority of the MU was within the buffer.

${ }^{2}$ Area of a buffer is in $\mathrm{km}^{2}$. Area covered by a given fixed buffer in addition to half-mile or one-mile buffers placed around all molt units that were partially covered by that fixed buffer (greater than; 50-percent overlap). Values in parentheses are percentages of the Goose Molting Area inside the Teshekpuk Lake Special Area that is included in a buffer. 
Table 2. Summary statistics for numbers and percentages of goose and swan populations included in selected layers based on thresholds that include 70-90 percent of the total population.

[A 1.6-km (1-mile) buffer along the Beaufort Sea Coast and a $4.8 \mathrm{~km}$ (3-mile) buffer around Teshekpuk Lake were included in all scenarios. Percentages are shown in parentheses, whereas absolute values (for area covered, number of birds) are not. Area and population percentages are in relation to the Goose Molting Area within the Teshekpuk Lake Special Area, as outlined in the 2013 NPR-An Integrated Activity Plan Record of Decision. Separate rankings are based on the distributions of black brant (BLBR) and Canada geese (CAGO). The header row indicates the species used for selecting molt units based on population density. The stated threshold of protection for each scenario in this report assumes that the buffers around molt units are wide enough to alleviate behavioral and energetic consequences of disturbance.]

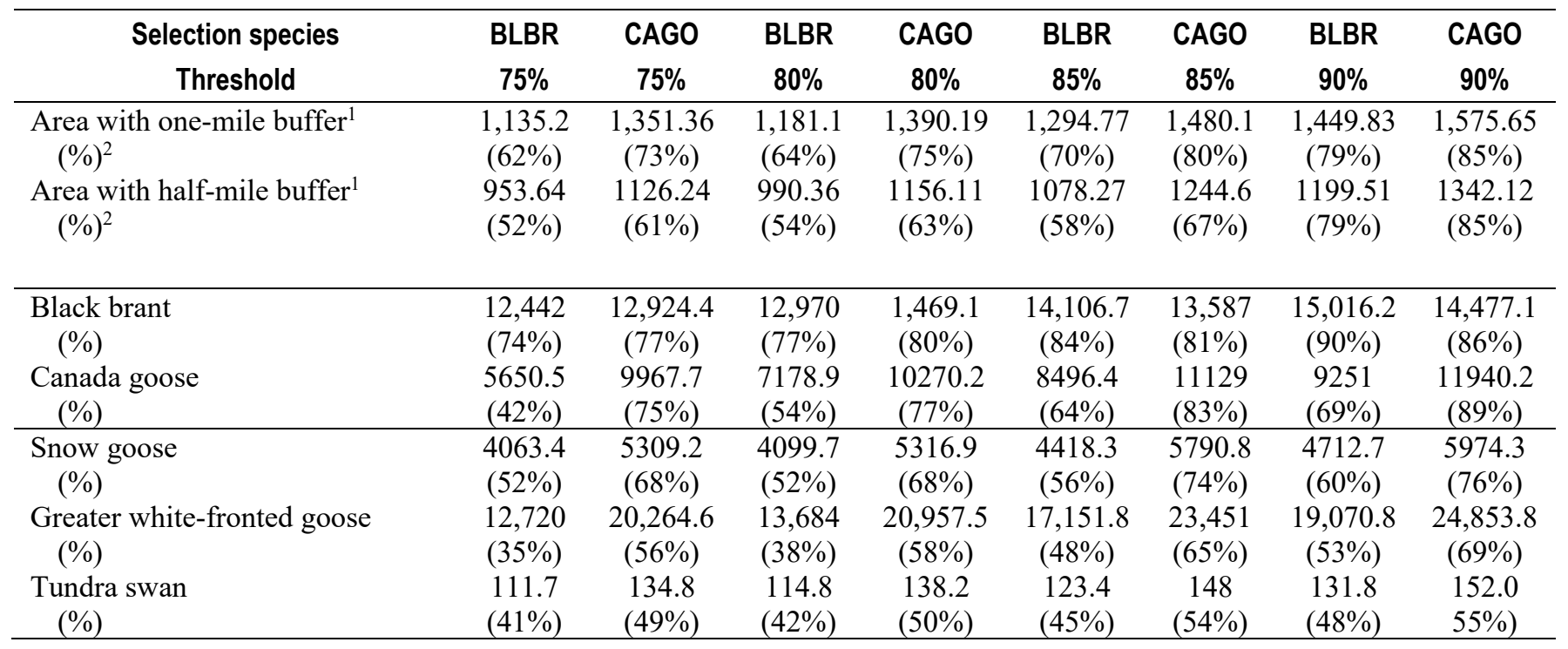

${ }^{1}$ Area of a buffer is in $\mathrm{km}^{2}$. This includes buffers around all selected molt units as well as the area of the 1-mile fixed buffer along the coast and the 3-mile fixed buffer along the shore of Teshekpuk Lake. Both fixed buffers were included in all scenarios.

${ }^{2}$ Percentage of the Teshekpuk Lake Special Area that is included in a buffer. 
A

Selection based on Molt Unit BLBR population density

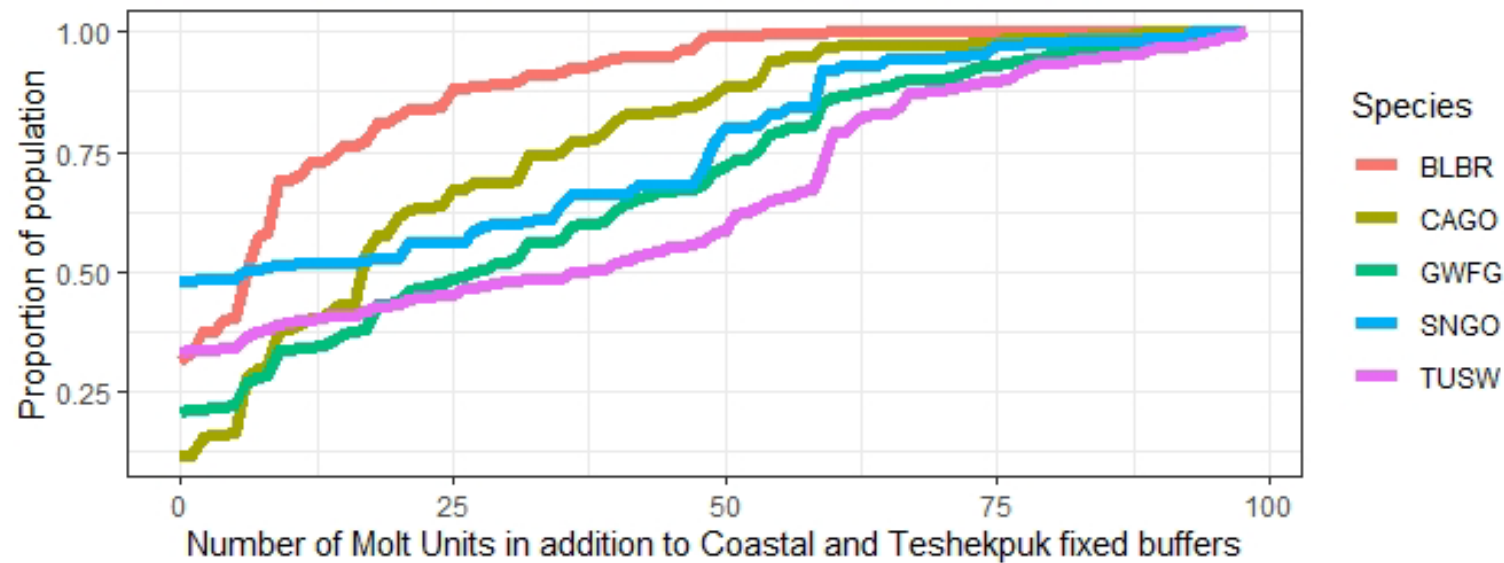

B

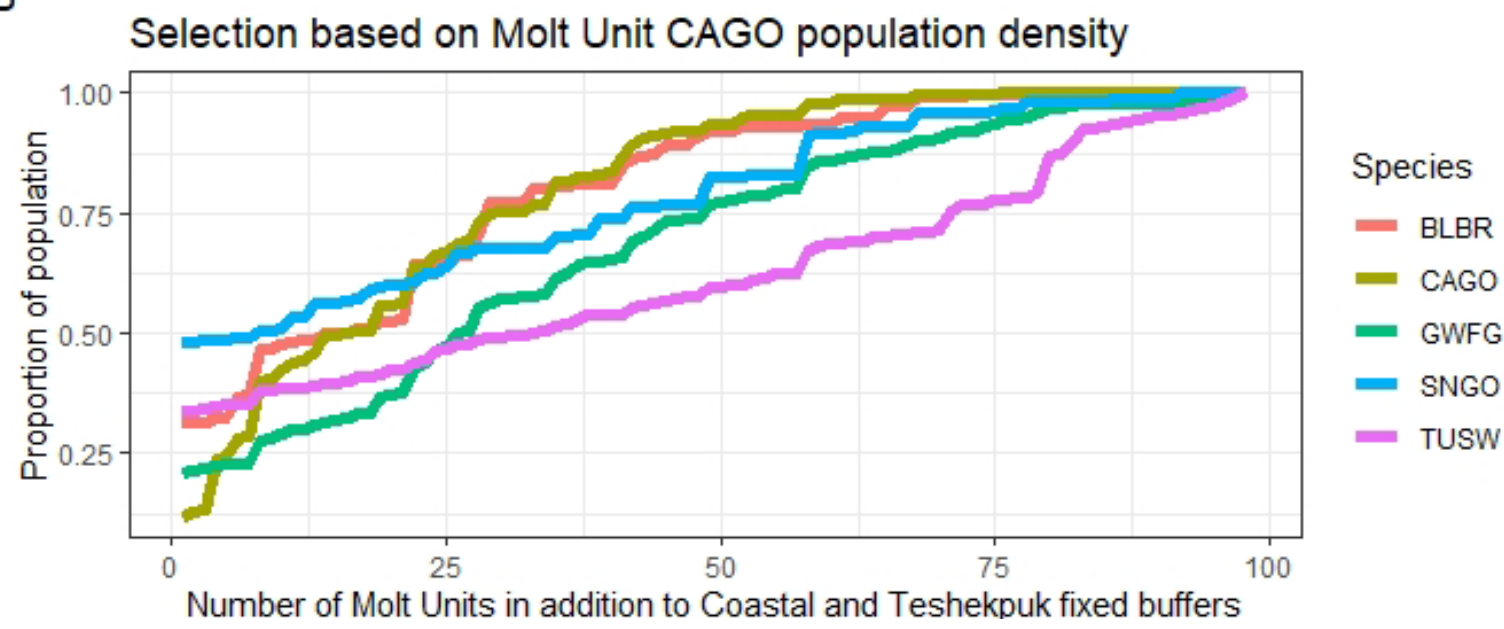

Figure 3. Cumulative proportion of geese and swans included when molt units in the Goose Molting Area of the Teshekpuk Lake Special Area were selected based on (A) population density of black brant (BLBR) and (B) Canada geese (CAGO). Molt unit selection was based on population density of the selected species to ensure that the desired population threshold could be achieved using the minimum number of molt units. These graphs represent the relative gain by adding molt units to pre-defined Coastal and Teshekpuk Lake buffers. The proportions represented when zero molt units are included represents the birds occurring within the two fixed buffers. Species abbreviations are black brant (BLBR), Canada goose (CAGO), greater white-fronted goose (GWFG), snow goose (SNGO), and tundra swan (TUSW). The stated levels of population coverage assume that the buffers around molt units are wide enough to alleviate behavioral and energetic consequences of disturbance. 
BLBR $75 \%$ population

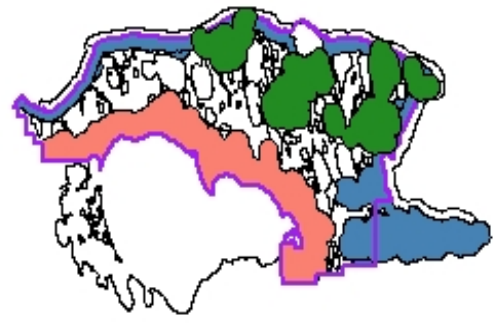

BLBR $80 \%$ population

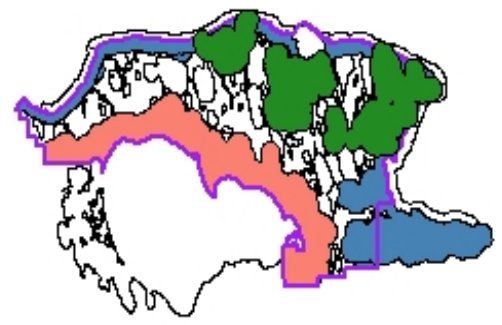

BLBR $85 \%$ population

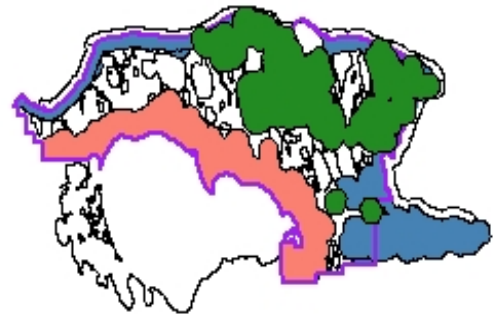

BLBR $90 \%$ population

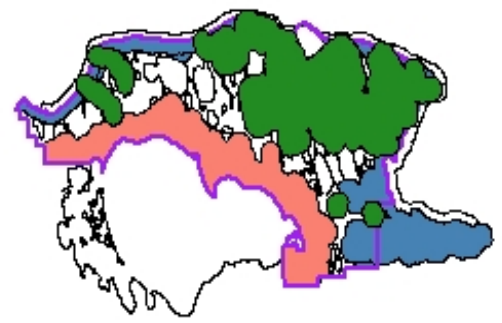

CAGO $75 \%$ population

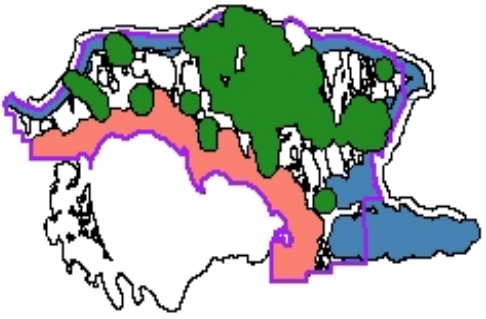

CAGO $80 \%$ population

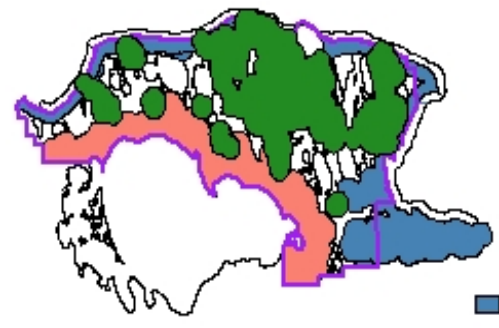

CAGO $85 \%$ population

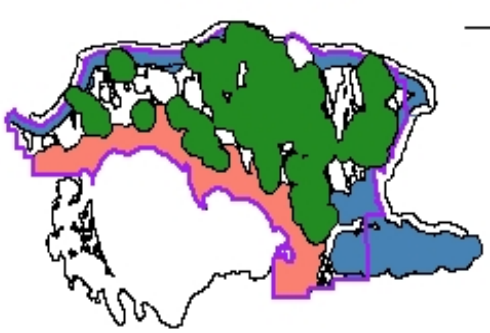

CAGO $90 \%$ population

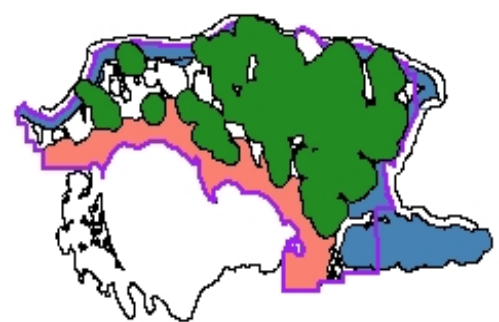

Figure 4. Map representations showing selected priority habitats for black brant and Canada geese northeastern part of the goose-molting area, Teshekpuk Lake Special Area of the National Petroleum Reserve, Alaska. The title for each map representation describes the prioritization used for each specific map. For example, "BLBR 75percent population" represents the minimum area that included 75 percent of the black brant population counted in the Goose Molting Area of the Teshekpuk Lake Special Area (TLSA) between 2010 and 2016. Each scenario included fixed coastline and Teshekpuk Lake buffers, with $1.6 \mathrm{~km}$ (one-mile) buffers added around molt units selected to achieve the stated level of coverage. The stated level of protection for each scenario in this report assumes that the buffers around molt units are wide enough to alleviate behavioral and energetic consequences of disturbance. (black brant, BLBR; Canada goose, CAGO) 
The scenarios in this report represent potential surface-occupancy restrictions on $954-1,576 \mathrm{~km}^{2}$ within the Goose Molting Area (52-85 percent of surface area in the Goose Molting Area, or 6-10 percent of the total surface area in the 2013 ROD boundaries of the TLSA), depending on the choice of target species, population threshold, and buffer width (table 2). For example, if the selection criteria were 85 percent of the black brant population, half-mile buffers around selected MUs would cover a total of $1,078 \mathrm{~km}^{2}$, while one-mile buffers would cover $1,295 \mathrm{~km}^{2}$, or an additional 12 percent of total surface area in the Goose Molting Area (table 2; fig. 5). Wider buffers with surface occupancy and (or) new infrastructure restrictions would also limit the placement of linear development features like roads and pipelines (fig. 5).

Spatial data layers showing the extent of potential surface-occupancy restrictions under the various scenarios in this report can be found in Patil and others (2020). 


\section{BLBR $85 \%$ one-mile buffer}

A

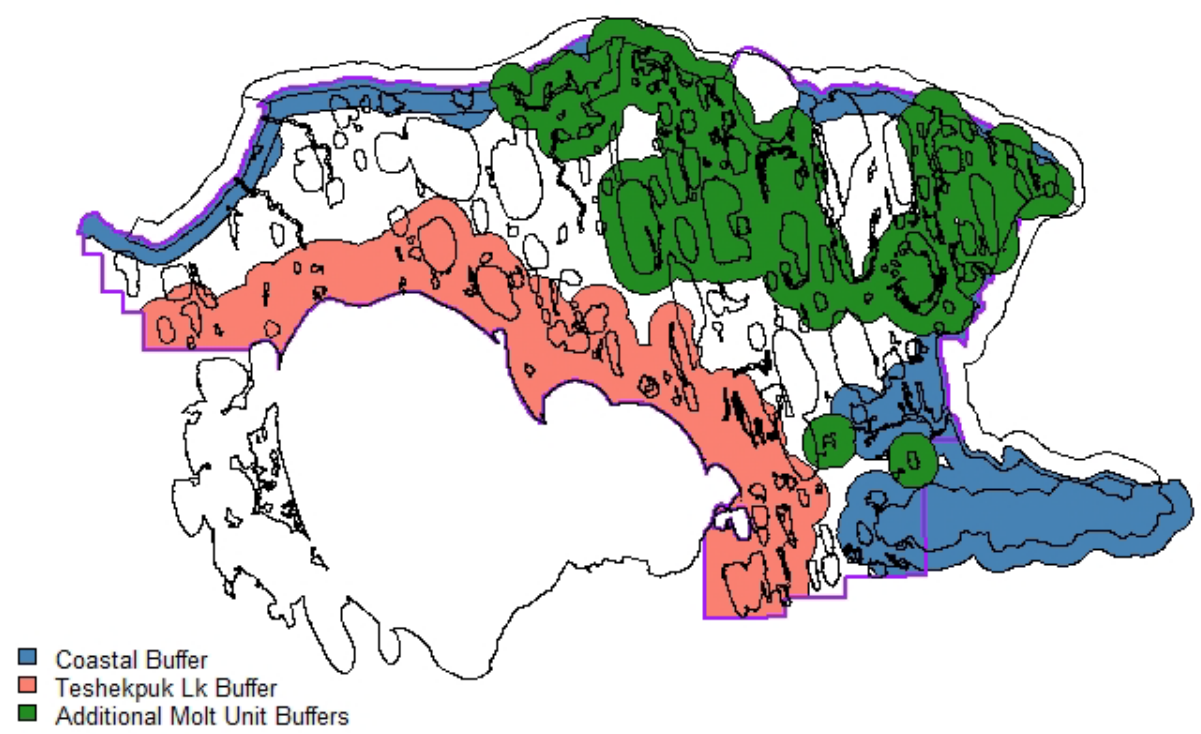

BLBR $85 \%$ half-mile buffer

B

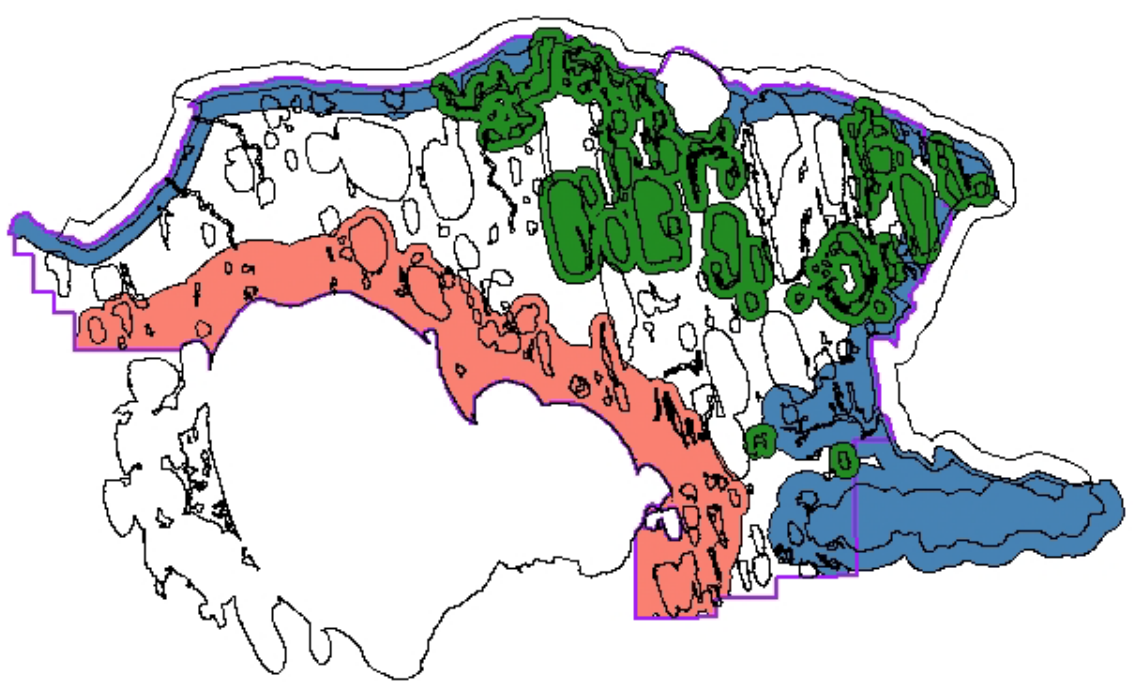

Figure 5. Comparison of two molt-unit buffer scenarios in the Teshekpuk Lake Special Area of the National Petroleum Reserve, Alaska. Map representations show a set of molt units composing 85 percent of the Teshekpuk Lake Special Area (TLSA) molting black brant population that were calculated based on average population densities from 2011--2016. (A) comprises $1.6 \mathrm{~km}$ (one-mile) no-surface-occupancy buffers around all selected molt units and is identical to the 85-percent BLBR map in Figure 4, while (B) shows the extent of $0.8 \mathrm{~km}$ (half-mile) buffers. When undisturbed, molting black brant rarely use habitat more than one-half mile from the lakeshore (Lewis and others, 2011); however, the half-mile buffers do not account for the effects of disturbance on black brant behavior. The one-mile buffer scenario expands the zone of surface-development restrictions around each molt unit to reduce the potential for disturbance. The stated level of protection for each scenario in this report assumes that the buffers around molt units are wide enough to alleviate behavioral and energetic consequences of disturbance. (black brant, BLBR; Canada goose, CAGO) 


\section{Discussion}

The maps we developed represent the minimum area of habitat used by the stated percentage of geese, which was determined for the most recent years when complete aerial surveys were conducted over the entire Goose Molting Area (2010-16). Molt units were selected for priority classification on the basis of objective criteria (the population density of a desired species), a method that is efficient (in terms of area required), objective, and repeatable. Although Canada geese were distributed similarly to black brant, they were more widely dispersed, and habitat selection focused on black brant required a smaller area to reach a given threshold of population coverage for the target species; however, selection focused on Canada geese was more broadly inclusive of other species. Although the primary goal of the TLSA is to provide habitat protection for molting black brant, selection based on black brant habitat might not be the optimal strategy for protecting all other species of waterfowl in the area. These results highlight the importance of defining clear management priorities when designating land for development restrictions.

Regardless of the focal species used for habitat selection, the stated level of protection (percentage of population) for each scenario depends on the assumption that the buffers around MUs are wide enough to both allow access to grazing habitat and eliminate the negative behavioral and energetic consequences of disturbance. Limited data are available to evaluate this assumption for molting waterfowl in the TLSA, and our results should be interpreted with this caveat in mind. Half-mile buffers around selected MUs are likely to cover more than 90 percent of the grazing habitat used by geese (Lewis and others, 2011; Flint and Meixell, 2017). Half-mile buffers, however, may not be sufficient to prevent molting flocks from responding to disturbance from industrial activity. Based on experimental overflights, Jenson (1990) concluded that molting flocks of flightless black brant can react to an airborne helicopter that is up to $3.5 \mathrm{~km}$ away. Flocks frequently ran more than $100 \mathrm{~m}$ towards the nearest water body in response to an approaching helicopter, and geese have remained swimming for up to 45 minutes before returning to land (Jenson 1990). Computer simulations based on those findings indicated that molting black brant exposed to more than 50 overflights per day could experience significant weight loss (potentially reducing their survival probability), although these effects could be reduced by the use of smaller aircraft flying at an elevation above $600 \mathrm{~m}$ (Miller and others, 1994). In a separate study, Derksen and others (1982) noted that molting black brant flocks subjected to multiple aircraft disturbances could respond by swimming as far as $3 \mathrm{~km}$. Molting geese are easily disturbed by field biologists on foot as far as $500 \mathrm{~m}$ away (Derksen and others, 1982). They could also be sensitive to visual and auditory disturbance caused by industrial activity on the ground, such as processing facilities, construction, and road traffic, but we are unaware of studies that would allow us to estimate the magnitudes of those effects. Because of the limited available data, it is not clear whether half-mile or one-mile buffers around selected MUs would be sufficient to completely eliminate disturbance effects. These studies suggest a need for additional investigation into how development might affect the behavior, energetics, and population dynamics of molting waterfowl in the NPR-A.

Evaluation of the scenarios outlined in this report should consider the fact that molting goose populations in this area are changing in numbers and/or distributions. As of 2008, snow and whitefronted geese were increasing in abundance, whereas black brant and Canada geese numbers were stable (Flint and others, 2008). At the conclusion of their study, Flint and others (2008) found that black brant had moved away from inland freshwater lakes and were primarily molting along the coast in estuarine waters. The distribution of MUs with high black brant population density described in this report suggests that this pattern has continued in more recent years. Between 2010 and 2016, a single coastal MU (the Garry Creek Estuary) hosted almost 30 percent of the black brant population despite occupying 
less than 1 percent of the total surface area in the Goose Molting Area. The methods outlined here could be used to account for future population dynamics by selecting MUs based on increasing or decreasing trends rather than current distributions.

The scenarios we used were not designed to identify habitat used by waterfowl during the breeding season. A recent study found that industrial activity had little influence on the behavior of nesting white-fronted geese (Meixell and Flint, 2017). However, the Teshekpuk Lake region is used as nesting habitat by a variety of duck and goose species, including the Spectacled Eider (Somateria fischeri), a species listed as threatened under provisions of the Endangered Species Act, that may have different sensitivities to disturbance.

\section{Conclusions}

We have described an objective approach to defining priority habitats within the Goose Molting Area of the TLSA based on available data. This approach is dependent on three key criteria: (1) define any areas previously designated as protected for reasons not related to molting waterfowl, and quantify their value as molting habitat; (2) define the goals of the habitat-selection process in terms of species and proportions of population that should be protected; and (3) choose the buffer size to be included around additional habitat units on the basis of available data and a clear biological rationale (for example, protection of grazing habitat and(or) reduction of disturbance effects on molting geese). Once these steps have been completed, the methods outlined in this report will allow land managers to determine the minimum area of habitat that meets all specified criteria.

\section{References Cited}

Amundson, C.L., Flint, P.L., Stehn, R., Platte, P., Wilson, H.M., and Fischer, J., 2019, Spatio-temporal population change of Arctic-breeding waterbirds on the North Slope of Alaska: Avian Conservation and Ecology, v. 14, p. 18.

Bivand, R., Keitt, T., and Rowlingson, B., 2019, rgdal-Bindings for the "Geospatial” Data Abstraction Library: The Comprehensive R Archive Network website, accessed month day, year, at https://cran.rproject.org/package $=$ rgdal.

Bivand, R., and Rundel, C., 2019, rgeos-Interface to Geometry Engine-Open Source (GEOS): The Comprehensive R Archive Network website, accessed month day, year, at Retrieved from http://cran.r-project.org/package=rgeos.

Bollinger, K.S. and Derksen, D.V., 1996, Demographic characteristics of molting black brant near Teshekpuk Lake, Alaska: Journal of Field Ornithology, v. 67, p. 141-158.

Bureau of Land Management, 2008, Northeast National Petroleum Reserve-Alaska supplemental integrated activity plan-Record of decision: Bureau of Land Management, Anchorage, Alaska.

Bureau of Land Management, 2013, National Petroleum Reserve-Alaska Integrated Activity PlanRecord of decision: Bureau of Land Management, Anchorage, Alaska.

Bureau of Land Management, 2015, Supplemental environmental impact statement for the Alpine Satellite Development Plan for the proposed Greater Moose's Tooth One development projectRecord of decision: Bureau of Land Management, Anchorage, Alaska.

Derksen, D.V., Eldridge, W.D. and Weller, M.W., 1982, Habitat ecology of Pacific black brant and other geese moulting near Teshekpuk Lake, Alaska: Wildfowl, v. 33, p. 39-57.

Flint, P.L., Mallek, E., King, R.J., Schmutz, J.A., Bollinger, K.S., and Derksen, D.V., 2008, Changes in abundance and spatial distribution of geese molting near Teshekpuk Lake, Alaska-Interspecific competition or ecological change?: Polar Biology, v. 31, p. 549-556. [Also available at: https://doi.org/10.1007/s00300-007-0386-8]. 
Flint, P.L., and Meixell, B., 2017, Movements and habitat use of white-fronted geese during the remigial molt in Arctic Alaska: Waterbirds, v. 40, p. 272-281. [Also available at https://doi.org/10.1675/063.040.0308.]

Fox, A.D., Flint, P.L., Hohman, W.L., and Savard, J.-P.L., 2014, Waterfowl habitat use and selection during the remigial moult period in the northern hemisphere, p. 131-168 in Rees, E.C., Kaminski, R.M., and Webb, E.B. eds., Ecology and conservation of waterfowl in the Northern Hemisphere: Slimbridge, Gloucestershire, United Kingdom, Wildfowl and Wetlands Trust, Wildfowl Special Issue 4.

Hockin, D., Ounsted, M., Gorman, M., Hill, D., Keller, V., and Barker, M., 1992, Examination of the effects of disturbance on birds with reference to its importance in ecological assessments: Journal of Environmental Management, v. 36, p. 253-286.

Jensen, K.C., 1990, Responses of molting Pacific black brant to experimental disturbance in the Teshekpuk Lake Special Area, Alaska: Ph.D. Thesis, Texas A\&M University, College Station, Texas.

Lewis, T.L., Flint, P.L., Derksen, D.V., and Schmutz, J.A., 2011, Fine scale movements and habitat use of Black Brant during the flightless wing molt in Arctic Alaska: Waterbirds, v. 34, p. 177-185. [Also available at https://doi.org/10.1675/063.034.0206.]

Liebezeit, J., Kendall, S., Brown, S., Johnson, C., Martin, P., McDonald, T., Payer, D., Rea, C., Streever, B., and Wildman, A., 2009, Influence of human development and predators on nest survival of tundra birds, Arctic Coastal Plain, Alaska: Ecological Applications, v. 19, p. 1628-1644. [Also available at https://doi.org/10.1890/08-1661.1.]

Meixell, B.W., and Flint, P.L., 2017, Effects of industrial and investigator disturbance on Arctic-nesting geese: Journal of Wildlife Management, v. 81, p. 1372-1385, https://doi.org/10.1002/jwmg.21312.

Miller, M.W., Jensen, K.C., Grant, W.E. and Weller, M.W., 1994, A simulation model of helicopter disturbance of molting Pacific black brant: Ecological Modelling, v. 73, p. 293-309.

National Research Council, 2003, Cumulative environmental effects of oil and gas activities on Alaska's North Slope: Washington, D.C., National Academies Press, 4 p.

Patil, V. 2020, Habitat selection scenarios for molting waterfowl in the Goose Molting Area of the Teshekpuk Lake Special Area, for NPR-A Integrated Activity Plan/Environmental Impact Statement (2020): U.S. Geological Survey data release, https://doi.org/10.5066/P9ZGNRTB

R Development Team, 2019, R: A Language and Environment for Statistical Computing, Retrieved from http://www.r-project.org

Shults, B.S., and Zeller, T.K., 2017, Abundance and distribution of molting geese in the vicinity of Teshekpuk Lake, Alaska, July 2017: U.S. Fish and Wildlife Service Migratory Bird Management, Anchorage, Alaska, $15 \mathrm{p}$.

Tape, K.D., Flint, P.L., Meixell, B.W. and Gaglioti, B.V., 2013, Inundation, sedimentation, and subsidence creates goose habitat along the Arctic coast of Alaska: Environmental Research Letters, $\mathrm{v}$. 8, p. 045031.

U.S. Geological Survey, 2019, National Hydrography Dataset (ver. USGS National Hydrography Dataset Best Resolution (NHD) for Hydrologic Unit (HU) 4 - 2001 (published 20191002)), accessed October 23, 2019, at https://www.usgs.gov/core-science-systems/ngp/national-hydrography/accessnational-hydrography-products. 
Publishing support provided by the U.S. Geological Survey Science Publishing Network, Tacoma Publishing Service Center

For more information concerning the research in this report, contact the Director, Alaska Science Center

U.S. Geological Survey

4210 University Drive

Anchorage, Alaska 99508

https://www.usgs.gov/centers/asc/ 


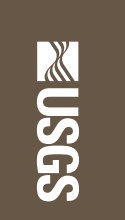

끌

를

웅

공.

골.

I

产

을

즐

产

密

要

产

용.

풀

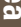

क्ञ

룽

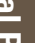

要

罗

蕜 